\title{
Sistem Pembelajaran Dari Rumah Melalui Model Daring TK Al Muhajirin Kota Malang Saat Pandemi Covid-19
}

\author{
Dessy Farantika(1), Dwi Indrawati ${ }^{(2)}$, \\ ${ }^{1}$ PIAUD, FAI, Universitas Nahdlatul Ulama Blitar, Indonesia \\ 2, TK Al Muhajirin Kota Malang, Indonesia \\ Email: ${ }^{1}$ farantika.dessy@gmail.com, ${ }^{2}$ dwiindrawati777@gmail.com
}

\begin{abstract}
Abstrak: Sistem pembelajaran dari rumah melalui model dalam jaringan saat pandemi Covid-19 merupakan salah satu sistem pembelajaran yang dilakukan dirumah yang melibatkan kerjasama antara orangtua dan sekolah untuk tetap melaksanakan pembelajaran melalui bermain. Pembelajaran ini untuk mestimulus perkembangan anak melalui kegiatan yang dirancang oleh guru dan dilaksanakan oleh orangtua dirumah bersama anak dengan pendampingan guru. Fokus penelitian ini digunakan untuk menjawab tentang perencanaan, pelaksanaan, evaluasi dan kendala sistem pembelajaran melalui bermain dari rumah melalui model dalam jaringan $\mathrm{TK}$ Al Muhajirin Kota Malang. Pemilihan metode penelitian kualitatif
\end{abstract} dengan pendekatan studi kasus untuk mengetahui secara mendalam dan terfokus.

\section{Tersedia Online di}

http://journal.unublitar.ac.id/pendidikan/i

ndex.php/Riset_Konseptual

\section{Sejarah Artikel}

Diterima pada: 28-01-2021

Disetuji pada: $30-01-2021$

Dipublikasikan pada: 31-01-2021

\section{Kata Kunci:}

belajar dari rumah, pelaksanaan, evaluasi dan kendala.

DOI:

http://doi.org/10.28926/riset_konseptual.v5i1.326

\section{PENDAHULUAN}

Penyebaran virus covid-19 (corona) pada akhir bulan Desember tahun 2020 yang berlokasi di Wuhan, China pemerintah setempat mengambil langkah untuk melakukan isolasi wilayah tersebut. Covid-19 merupakan masalah di bidang kesehatan bagi seluruh warga dunia. Terkait permaslahan tersebut World Health Organization (WHO) menjelaskan bahwa virus covid-19 merupakan wabah yang menyebar di seluruh dunia disebabkan banyaknya total keseluruhan negara yang terkena imbas dari virus tersebut sebanyak dua ratus tigabelas negara dengan jumlah kasus yang terinfeksi sekitar tiga juta orang di seluruh dunia dengan korban meninggal dunia mencapai lebih dari dua ratus ribu orang ("Kronologi dan Urutan Munculnya 6 Orang Positif Virus Corona di Indonesia.," 2020). Wabah ini meluas dengan begitu pesat ke seluruh dunia salah satunya di Indonesia diperkirakan bulan Maret 2020. Dampak covid-19 yang menyebar ke Indonesia menyebabkan berbagai perubahan di berbagai ranah kehidupan. Berbagai peraturan telah diambil oleh pemerintah Indonesia untuk menangulangi tingginya meluasnya virus corona dengan menerapkan sosial distancing, physical distancing hingga penerapan PSBB (Pembatasan Social Berskala Besar) dilaksanakan di beberapa daerah.

Peraturan-peraturan yang diterapkan untuk menangulangi meluasnya virus corona menimbulkan dampak pada berbagai ranah kehidupan. Salah satu ranah yang terkena imbas akibat virus corona ini adalah pendidikan. Berbagai peraturan diambil oleh Kemendikbud untuk menangulangi penyebaran virus di lingkungan pendidikan. Salah satu penentapan peraturannya yaitu keputusan menteri No 2 Tahun 2020 dan No 3 Tahun 2020 Menteri Pendidikan dan Kebudayaan (Mendikbud) yang berisi tentang mengambil langkah penerapkan kebijakan pemerintah daerah untuk melaksanakan pembelajaran dirumah dan menonaktifkan kegiatan belajar mengajar disekolah. Kemendikbud siap mendorong untuk penerapan sistem pembelajaran jarak jauh. 
Dengan adanya keputusan tersebut dari Menteri Pendidikan dan Kebudayaan RI ini menuntut seluruh lembaga pendidikan untuk melaksanakan pembelajaran dalam jaringan atau disebut pembelajaran daring agar pelaksanaan pendidikan tetap terlaksanakan dengan model terpisah atau pembelajaran jarak jauh antara guru dan peserta didik. Program pemerintah yang dilaksanakan untuk proses pendidikan dari rumah atau jarak jaruh antara guru dan peserta didik dikenal dengan istilah "Belajar dari Rumah" untuk siswa dan "Bekerja dari rumah" untuk tenaga pendidik menjadi meluas ("Pemerintah Tetapkan Status Wabah Covid-19 Sebagai Bencana Nasional," 2020). Sistem pembelajaran dari rumah dilakukan secara terpisah atau daring dengan menggunakan teknologi komunikasi yang disepakati dari rumah. Beberapa pemerintah daerah mengambil keputusan melaksanakan kebijakan untuk menonaktifkan kegiatan sekolah dan mulai melaksanakan proses pembelajaran dengan sistem daring (dalam jaringan) atau online pada tanggal 18 maret 2020 akibat penerapan peraturan pemerentah ini Kurniati, Kusumawanita dan Adriani (2020) menyatakan pandemi ini membuat para guru, orang tua dan siswa untuk belajar dalam pelaksanaan proses pembelajaran tradisional menjadi pembelajaran jarak jauh dikarenakan keterbatasan waktu, lokasi dan jarak di waktu pandemi ini. Pembelajaran jarak jauh menjadi alternatif untuk mengatasi kendala dalam melaksanakan proses pembelajaran secara tatap muka langsung selama pandemi covid-19. Proses pembelajaran daring ini menuntut kepada seluruh komponen pendidikan dan tingkat pendidikan untuk mempertahankan kelas tetap aktif meskipun proses pembelajaran berubah. Guru sebagai pemeran penting dalam pelaksanaan pembelajaran dituntut membuat perubahan secara signifikan yang belum pernah terjadi sebelumya dari pendidikan tatap muka tradisional ke pendidikan online atau pendidikan jarak jauh. Perubahan pelaksanan pembelajaran ini sejalan dengan pertumbuhan teknologi yang tidak terbatas pada revolusi industry 4.0 saat ini untuk melaksanakan pembelajaran daring (Bao, 2020). Pembelajaran daring efisien untuk dilaksanakannya pembelajaran meskipun berada di tempat yang berbeda untuk guru dan siswa.

Dengan adanya kebijakan ini, pelaksanaan kegiatan belajar mengajar dengan model klasikal berubah menjadi pembelajaran jarak jauh atau dalam jaringan (daring). Dengan ini semua lembaga pendidikan di Indonesia tanpa kecuali lembaga pendidikan di Kota Malang, khususnya lembaga yang diteliti peneliti tepatnya di TK AI Muhajirin juga melaksanakan pembelajaran jarak jauh atau dengan model dalam jaringan (daring). Berbagai kegiatan dirancang untuk proses pembelajaran anak mengganti kegiatan selama berada di rumah yang akan membuat anak tidak mengalami kejenuhan. Selain itu, pelaksanaan pembelajaran anak juga tetap berjalan meski dirumah untuk membuat anak tidak melukan proses pembelajar di sekolah mereka melalui aktivitas pembelajarannya yang sudah dirancang dan dijadwalkan untuk dilaksanakan dirumah bersama orangtua. Guru sebagai penanggungjawab dalam pelaksanaan kegiatan pembelajaran harus tetap melakukan pendampingan untuk mengetahui proses belajar anak ketika kegiatan pembelajaran dilaksanakan di rumah sehingga akhirnya setiap anak tetap memperoleh penilaian dari proses pembelajarannya dari stimulus atau kegiatan yang diberikan oleh orangtua. Hal lain dikuatkan dengan pernyataan lbu Indrawati selaku Kepala Sekolah TK AI Muhajirin Kota Malang menyatakan "hal pertama yang dilakukan oleh sekolah saat terjadinya proses pembelajaran dari rumah yang disebabkan covid-19 yaitu melakukan koordinasi dan pengambilan keputusan sistem belajar bersama orangtua". Pengambilan keputusan pembelajaran ini dilaksanakan antara orangtua dan sekolah untuk mengetahui kondisi di masing masing keluarga. Proses pembelajaran setiap keluarga berbeda yang disebabkan oleh latarbelakang keluarga. Hal ini diperkuat dengan wawancara dengan lbu Fitri guru Kelas Kelompok B TK Al Muhajirin Kota Malang menyatakan "harus ada kerjasama antara guru dan orangtua untuk melaksanakan pembelajaran dari rumah. Hal ini, diakibatkan terkendalanya tempat dan waktu dalam pelaksanaan pembelajaran daring. Selain itu, guru juga diharapkan mampu membuat sebuah trobosan untuk kegiatan pembelajaran sekreatif mungkin dan mengetahui latarbelakang kondisi dirumah untuk bahan 
pembelajaran yang kiranya bisa memanfaatkan barang barang yang ada dirumah". Selain itu perlu juga memperhatikan dari sisi kesiapan lembaga sekolah dalam perencanaan dan pelaksanaan, lembaga juga harus melihat kondisi yang akan melakukan pendamping anak selama proses pembelajaran dirumah. Hal ini dijelaskan oleh Ibu Dwi selaku kepala sekolah TK Al Muhajirin Kota Malang menyatakan bahwa "pendampingan anak saat pelaksanaan pembelajaran dari rumah juga perlu diperhatikan sebab tidak sedikit dari wali murid yang bekerja dan anak didampingi oleh nenek dan kakeknya. Selain itu, juga perlu memperhatikan fasilitas terutama teknologi yang dimiliki keluarga tersebut". Hasil dari paparan data wawancara awal, peneliti tertarik untuk melakukan penelitian tentang proses pelaksanaan pembelajaran model dalam jaringan (daring) di TK Al Muhajirin Kota Malang dengan rumusan penelitian: (1) bagaimana pelaksanaan pembelajaran model dalam jaringan (daring) di TK Al Muhajirin Kota Malang? (2) bagaimana pelaksanaan evaluasi pembelajaran model dalam jaringan (daring) di TK Al Muhajirin Kota Malang?. (3) bagaimana kendala pelaksanaan pembelajaran model dalam jaringan (daring) di TK Al Muhajirin Kota Malang?. Dengan beberapa rumusan penelitian ini, peneliti ingin pelaksanaan model dalam jaringan (daring) di TK Al Muhajirin Kota Malang, sehingga kemudian penulis tertarik untuk melakukan penenlitian tentang "SISTEM PEMBELAJARAN DARI RUMAH MELALUI MODEL DALAM JARINGAN TK AL MUHAJIRIN KOTA MALANG SAAT PANDEMI COVID"

\section{METODE}

Untuk mengali data dalam pelaksanaan penelitian ini metode menggunakan studi kasus dengan pendekatan penelitian kualitatif. pemilihan metode Studi kasus ini bertujuan untuk mengali data secara mendalam agar diperoleh paparan data suatu fenomena yang sedang berlangsung dan berfokus pada suatu kasus pada kelompok, sehingga dapat memberika informasi yang penting untuk menjawab dari permasalahan yang muncul(Hodgetts \& Stolte, 2012). Dalam hal ini penelitian menganalisis proses pelaksanaan pembelajaran dari rumah melalui model dalam jaringan di TK Al Muhajirin Kota Malang saat pandemi Covid-19 terjadi. Subjek dalam penelitian ini sejumlah 6 orang, yaitu 2 orang guru, 1 orang kepala sekolah dan 3 orang orangtua TK Al Muhajirin Kota Malang yang memiliki latar belakang keluarga yang berbeda. Latar belakang keluarga yang berbeda disini yaitu ibu bekerja, ibu rumah tangga dan anak didampingi oleh saudara. Lokasi penelitian ini di TK Al Muhajirin Kota Malang dan pelaksanaan penelitian dilakukan pada Tanggal 23 Maret 2020-18 April 2020. Metode pengambilan data selama penelitian ini menggunakan teknik wawancara dan dokumentasi. Sedangkan untuk metode menganalisis data digunakan model analisis data Miles dan Huberman yaitu reduksi data, display data dan kesimpulan atau verifikasi tentang sistem pembelajaran dari rumah. Sedangkan tahap uji keabsahan data yaitu : triangulasi sumber, triangulasi metode, triangulasi teknik dan triangulasi teori.

\section{HASIL dan PEMBAHASAN HASIL}

Setiap penelitian tentunya ada pemaparan data dari hasil penelitian yang dilaksnakan oleh peneliti. Data hasil temuan penelitian ini sebagai data penguat untuk melakukan kajian penelitian sesuai dengan rumusan dalam penelitian. Fokus dalam penelitian ini adalah sistem pembelajaran dari rumah melalui model dalam jaringan TK Al Muhajirin Kota Malang saat pandemi covid-19 peneliti dalam menyajikan data penelitian menggunakan tiga jenis pengambilan data yaitu data hasil observasi dan data hasil interview dan dokumentasi model pelaksanaan sistem pembelajaran dari rumah TK AL Muhajirin Kota Malang. Oleh karena itu, peneliti akan mendeskripsikan hasil temuan yang didapat dari hasil lapangan seperti berikut : 


\section{Pelaksanaan Pembelajaran Dari Rumah TK AI Muhajirin Kota Malang Saat Pandemi Covid 19}

Langkah pertama yang dilakukan saat diterpkannya untuk pelaksanaan pembelajaran dari rumah untuk pencegahan Covid-19 TK Al Muhajirin Malang melakukan rapat koodinasi untuk menyusun draf rencana pembelajaran dari rumah mulai dari SOP, RPPH, sistem pembelajaran yang akan diterapkan dan koordiansi dengan seluruh warga sekolah. pernyataan tersebut diperkuat oleh ibu indrawati selaku kepala sekolah "saat akan menerapkan pembelajaran dari rumah kami melakukan raapat internal antara kepala sekolah dan seluruh guru untuk menyusun dan mendiskusi draf pelaksanaan Belajar Dari Rumah atau di sebut BDR". Pelaksanaan pembelajaran dari rumah TK Al Muhajirin saat pandemi melibatkan kerjasama dengan orangtua agar terlaksana sesuai harapan. Hal ini diungkapkan oleh ibu fitri selaku guru kelompok B, beliau mengatakan "bahwa sekolah melakukan koordinasi untuk persiapan pembelajaran anak dirumah kepada para orangtua. pelaksanaan pembelajaran daring melibatkan orangtua sebagai pelaksana saat pembelajaran dirumah, selain itu sekolah menyiapkan group whatsapp khusus bagi orangtua selama belajar dari rumah. hal lain yang perlu disepakati adalah waktu belajar dan sistem pemeblajarannya". Pernyataan tersebut ditambahkan oleh ibu indra selaku kepla sekolah menyatakan bahwa "adanya koordinasi dengan walimurid yang akan menjadi guru dirumah bagi anak anaknya. Terdapat beberapa hal yang perlu disepakati antaralain kontrak belajar untuk pelaksanaan BDR, pembagian kelompok belajar berdasarkan orantua, mksdnya disini orangtua yang harus tetap bekerja di kantor dan anak yang tinggal bersama nenek atau kakakenya. Jadi pembelajaran tidak melulu dilakukan di pagi hari, pembelajaran dibagi menjadi 3 waktu yaitu pagi, sore dan malam hari berdasarkan kesepakata dan kesibukan orangtua." Kemudian guru menyiapkan tema-tema untuk belajar anak selama di rumah yang akan dibagi setiap minggu melalui orangtua, orangtua berkumpul setiap minggunya untuk mendapatkan pengarahan pembelajaran selama seminggu dan bahan pembelajaran yang kiranya perlu disiapkan oleh sekolah. Pernyataan tersebut dikuatkan oleh bu didin selaku guru kelompok A "mengadakan kelas orangtua wali murid untuk melakukan tatap muka dengan tetap memeperhatikan protokol kesehatan dengan cara membagi di breberapa waktu pertemuan seminggu sekali untuk mendapatkan pengarahan pembelajaran selama seminggu yang akan dilaksanakan. Materi yang diberikan dalam bentuk kegiatan, pembelajaran yang dilaksanakan dengan menggurangi sistem lembar kerja siswa jadi lebih ditekankan pada proses kegiatan". Hal ini dilaksanakan agar anak belajar secara langsung melalui proses hingga selesai. Itu sebabnya dalam merancangan pembelajaran yang dilakukan tidak sama seperti pada saat pembelajaran di sekolah dengan menggunakan tema-tema yang di siapkan oleh guru. Pelaksanaan pembelajaran dirumah tidak berbasis tema disebabkan sekolah dan orangtua lebih menekankan pada kecakapan hidup anak melalui kegiatan bermain dirumah bersama orangtua. Ibu fitri menambahkan bahwa "Pada saat seperti ini guru dituntut kreatif dan inovatif dalam melaksanakan pembelajaran daring, kegiatan belajar menyenangkan dan dapat menjadi wahana pembelajaran. Ini yang memang direncanakan dari awal oleh sekolah kami, pembelajaran tidak lagi berbasis tema seperti pada saat di sekolah. Tetapi lebih menekankan pada kegiatan membantu orangtua yang disisipi pembelajaran. Itu sebabnya guru juga harus memperhatikan penggunaan alat bahan yang ada dirumah agar orangtua tidak kesulitan dalam melaksanakan pembelajaran. Bahan atau media pembelajaran yang digunakan berbasis bahan bahan yang ada dirumah, loose part". Pelaksaan pembelajaran ini dirancang untuk mengajak anak-anak bermain sambil belajar dengan tujuan untuk memberikan samangat untuk tetap belajar walaupun ada di rumah dan merangsang seluruh aspek perkembangan anak agar tetap dapat berkembang secara maksimal. Hal itu juga dapat merangsang kreativitas siswa dan melatih anak untuk pemecahkan masalah.

Pembelajaran yang dilaksanakan di TK AI Muhajirin kota Malang dilaksanakan di rumah dengan sistem aplikasi daring yang atas pengarahan dari kepala sekolah dan guru kepada orangtua dan orangtua yang mensimulasikan pembelajaran anak setiap 
hari selama anak di rumah. Sebagaimana hasil wawancara dengan kepala sekolah lbu Dwi Indrawati, beliau mengatakan: "proses pelaksanaan pembelajaran daring selama liburan sekolah dikarenakan pandemi Covid-19. Pembelajaran anak diserahkan kepada orang tua, tetapi sekolah tetap mendampingi orang tua dalam menemani anak belajar di rumah. Setiap pagi guru memberikan pengarahan kepada orang tua, bahkan guru bisa setiap hari mengingatkan orang tua terkait belajar anak, semisalnya, hari ini anak akan belajar apa di rumah atau anak akan beraktivitas apa di rumah. selain itu guru juga melakukan videocall secara bergantian dengan murid untuk mengetahui perkembangan anak. hal lain yang dilakukan guru setiap harinya adalah kegiatan mengaji dan membaca tetap dalam pengawasan guru langsng dengan cara melakukan videocall satu persatu". Dalam pelaksanaan program anak belajar di rumah, Kepala TK Al Muhajirin selalu mendapingi orang tua melalui media whatsapp dan sekolah tidak lepaskan tangan semuanya diserahkan ke orang tua. Kepala sekolah meminta para guru setiap pagi untuk mngingatkan dan memberikan pengarahan dan pendampingan kepada orang tua tentang apa yang akan dipelajari anak setiap hari dan melakukan evaluasi setiap harinya kendala yang dihadapi oleh orangtua.

Pelaksanaan pembelajaran di rumah bagi anak-anak dengan kegiatan projek yang disesuakan dengan kegiatan yang ditentukan. Hal ini, dilakukan untuk mengembangkan seluruh aspek perkembangan anak. Sebagaimana diungkapkan oleh Ibu Fitri, beliau mengatakan: "projek dipilih sesuai dengan kegiatan seperti membuat minuman kesukaan. Kegiatan tersebut ini dilaksanakan untuk menstimulus seluruh perkembangan anak dan tujuannya untuk memfasilitasi anak dalam menuangkan kreatifitas anak dalam merencanakan projek. Kegiatan ini, biasa guru mengarahkan kepada orang tua untuk mengajak anak di dapur pada saat memasak di pagi hari dengan tujuan untuk mengembangkan kemampuan motorik kasar dan social-emosional anak biar bisa berkembang secara baik".

Selain itu, model pelaksanaan program kegiatan belajar anak di rumah dilakukan dengan bentuk kegiatan membaca doa-doa pendek, bernyanyi dan kegiatan tidak dilakukan dengan menggunakan lembar kegiatan siswa tetapi lebih berbasis projek yang dihasilakan dihari tersebut. sebagaimana diungkapkan oleh ibu lastri selaku wali murid, beliau mengatakan: "Selama libur wabah Corona ini setiap akan melakukan aktivitas orang tua membiasakan anak untuk membaca doa-doa pendek seperti anak mau mandi, mau makan, anak mau naik kenderan dan anak dibimbing untuk membaca surat-surat pendek. Selain itu juga bernyanyi bersama saat melakukan kegiatan. selain itu kegiatan anak berupa projek jadi anak dituntut untuk kreativitas dengan bahan dan alat yang ada dirumah. Memang kegiatan ini yang disarankan oleh sekolah tentang pendampingan anak selama belajar dirumah". Disaat pembelajaran dari rumah orangtua dan guru harus melakukan kerjasama yang baik agar seluruh aspek perkembangan anak dapat berkembang melalui kegitan kegiatan yg dapat menstimulus anak

\section{Evaluasi Pembelajaran Dari Rumah TK AI Muhajirin Kota Malang Saat} Pandemi Covid 19

Evaluasi merupakan kegiatan yang dilakukan oleh pendidik dengan pengumpulan informasi untuk menentukan kualitas dan kuantitas perkembangan belajar peserta didik. Evaluasi di TK AI Muhajirin dilakukan oleh guru kelas dengan model harian dan mingguan. Hasil evaluasi yang dikirimkan oleh wali murid selama proses bisa berbentuk gambar, video atau voicenote. Dari hasil tersebut dilihat untuk mengetahui proses belajar anak dirumah. Tujuan evaluasi bagi sekolah yaitu untuk melihat sejauh mana kemampuan anak dalam belajar di rumah selama wabah Covid-19 berlangsung. Berdasarkan data wawancara peneliti bersama dengan kepala sekolah TK AI Muhajirin Kota Malang Ibu Dwi Indrawati, beliau mengatakan:"evaluasi yang dilakukan oleh sekolah dengan model harian, di mana nanti guru setiap kelas akan selalu mengecek aktivitas anak di rumah yang biasanya dikirim ke grup. Selain itu biasanya guru juga menyapa anak dengan bercakap-cakap dengan anak melalui grup Whatsapp yang sudah berjalan ini, mulai dari tanya kabar anak-anak dan kadang menanyakan anak yang dilakukan pada saat itu. Dalam sistem pembelajaran dari rumah ini evaluasi lebih 
ditekankan pada proses anak bukan dari hasil". Diperkuat dengan pernyataan dari ibu fitri selaku guru Kelas kelompok B TK AI Muhajirin Kota Malang bahwa "proses evaluasi didapat dari hasil kiriman video, foto dan voicenote orangtua wali murid yang sedang melakukan pendampingan belajar, serta evaluasi dilakukan setiap hari oleh guru. Penekanan evaluasi pada ketuntasan anak melakukan suatu tugas bukan pada hasil"

Proses evaluasi pembelajaran yang dilaksanakan oleh guru TK Al Muhajirin Kota Malang ini dengan model evaluasi setiap hari dengan checklist kegiatan yang di-upload orang tua di grup Whatsapp. Selain itu, guru dalam melakukan evaluasi dengan metode percakapan langsung dengan anak didik seperti menanyakan kabarnya dan menayakan aktifitas yang dilakukan di rumah selama proses pembelajaran daring menggunakan group video call yang sudah ditentukan oleh guru dan tiap harinya group tersebut berganti anggota. Hal ini dilakukan untuk tetap mengajarkan anak sosialisai dengan teman sebaya yang terus berganti meski hanya di videocall. Selain itu, hal ini juga untuk membangun keberanian anak menyampaikan pendapatnya.

Hal senada juga diungkapkan oleh guru kelas kelompok B lbu Fitri, beliau mengatakan: "Dalam evaluasi anak selama belajar dirumah. Biasanya saya dengan model pemberian tugas tanya jawab kepada ada anak seperti menceritakan proses dari hasil tugasnya yang sudah dikerjakan untuk diceritakan. Kadang juga saya memberikan tugas kepada anak lewat group WA yang sudah dibuat agar anak selalu rajin membantu ibunya di rumah seperti membantu memasak, menyapu dan mencuci, kegiatan tidak melulu tentang project tapi membatu orangtua juga dapat mengembangkan aspek perkembangan anak dan kemandirian anak".

Sebagaimana hasil wawancara peneliti dengan guru, salah satu kegiatan evaluasi yang dilakukan yaitu dengan memberikan projek membembuat mainan sesuai tema atau membantu memasak. Evaluasi ini biasanya dalam evaluasi pembelajaran anak dikenal dengan istilah hasil karya. Sedangkan perintah guru kepada anak untuk rajin membantu ibu di rumah dalam rangka evaluasi model penugasan kepada selama proses belajar di rumah. Hal lain, dalam evaluasi pembelajaran daring anak TK Al Muhajirin Kota Malang sebagaimana diungkapkan oleh Ibu Fitri, beliau menjelaskan: "Saya dalam melakukan evaluasi anak selama belajar di rumah dengan menggunakan tanya jawab atau wawancara kepada orang tua bagaimana belajar anak selama di rumah, dan sikapnya. Dalam penilaian terhadap aktivitas anak di rumah atau tugas yang dikerjakan anak biasanya saya di grup WA memberikan nilai dengan sebutan anak pintar, anak hebat, dan anak cerdas.

Evaluasi pembelajaran jarak jauh yang dilakukan di TK Al Muhajirin Kota Malang ini dengan model interview atau wawancara langsung dilaksnakan oleh guru kepada orang tua seputar kegiatan anak di rumah seperti membantu orang tua, bacaan anak tentang doa-doa dan surat pendek dan kegiatan keagamaan anak melalui media Whatsapp dan percakapan melalui media telepon seluler. Dalam penilaian terhadap aktivitas anak di rumah oleh guru dengan penyebutan seperti anak pintar, anak hebat, anak cerdas dan seratus.

Selain itu guru juga melakukan evaluasi setiap harinya setelah menerima hasil laporan dari orangtua untuk mengetahui hasil dari pembelajaran siswa apakah dengan cara atau media tersebut anak dapat memaksimalkan belajar untuk mengembangkan aspek perkembangannya.

\section{Kendala Pembelajaran Dari Rumah TK AI Muhajirin Kota Malang Saat Pandemi Covid 19}

Dalam keadaan atau situasi menghadapi sistem pembelajaran dari rumah saat pendemi covid 19 memiliki beberapa kendala dalam mendapingi Anak Belajar di Rumah yaitu sebagai berikut, yaitu pemaham orangtua terhadap tugas yang diberikan guru, terbatasnya fasilitas untuk melaksanakan pembelajaran, waktu pendampingan belajar anak bersamaan dengan waktu bekerja. Hal senada juga diungkapkan oleh guru kelas kelompok B Ibu Fitri, beliau mengatakan: "yang menjadi kendala guru adalah fasilitas alat dan bahan selama pembelajaran berlangsung, guru dituntut untuk sekreatif mungkin 
dan meninimalisir pengeluaran dana orangtua untuk membeli bahan ajar untuk pelaksanaan pembelajaran dirumah.

Permasalahan yang muncul untuk guru selama proses pembelajaran daring adalah penugasan yang diberikan kepada murid, terdapat beberapa murid yang dalam menyelesaikannya tidak sendiri adanya keikut sertaan orang tua dalam penyelesaiannya. Namun, terdapat beberapa oangtua yang tidak dapat mendampingi selama proses pembelajaran dirumah akibat bekrja, sehingga tidak pendampingan dalam pelaksanaan pembelajaran murid. Selain itu ada 10 dari 20 orangtua siswa yang masih harus tetap menjalankan aktivitas bekerja diluar rumah." Selain itu terdapat beberapa kendala lain dalam proses pembelajaran dari rumah diantaranya orangtua kurang memahami materi pembelajaran yang harus dilaksanakan dan kesulitan dalam menumbuhkan minat belajar anak. Hal ini diperjelas dengan pernyataan ibu sulastri salah seorang orang tua murid menyatakan bahwa "orangtua pekerja terkadang kesulitan dalam membagi waktu untuk mendampingi anak belajar dirumah, selain itu terkadang keterbatasan bahan dan alat yang ada dirumah membuat orangtua dituntut untuk kreatif dan inovatif". Hal lain juga disampaikan oleh ibu eni salah seorang wali murid menyatakan bahwa terkadang anak anak sulit untuk diminta belajar bersama orangtua.

Kepala sekolah TK Al Muhajirin Ibu Dwi Indrawati juga menambahkan bahwa "terdapat dua kelompok kendala yang dialami dalam kegiatan pembelajaran daring yaitu kemampuan pengajaran dan teknologi. Dalam kendala pengajaran hal ini merupakan kondisi baru yang dialami oleh seluruh sekolah dan belum pernah adanya pelatihan dan pendampingan khusus sebelumnya, untuk kendala teknologi kemampuan dalam mengoprasikan teknologi yang belum mahir, keterbatasan waktu, kurang tepat dalam pemilih penggunaan bahan pembelajaran, aplikasi, metode, evaluasi, dan kurangnya interaksi saat berlangsungnya pembelajaran akibat keterbatasan waktu orangtua berkerja, serta minimnya kepedulian orang tua siswa dalam pendampingan anak saat melakukan belajar di rumah; sedangkan untuk permasalahan teknologi berupa minimnya alat pendukung atau sering disebut prasarana berupa jaringan internet/wifi, sinyal yang lemah dari mobile phone, tidak adanya perangkat elektronik seperti smartphone, minimnya kemampuan dalam menggunakan perangkat elektronik pintar untuk mendukung pembelajaran daring sebagai sarana media pembelajaran jarak jauh." Karena jaringan yang lemah, menyebakan terganggunya komunikasi sehingga informasi ataupun materi yang disampaikan memerlukan waktu yang cukup lama untuk di terima oleh orang tua, atau pun sebaliknya. Hal ini merupakan faktor dari lokasi dan keterjangkuan jaringan yang berada di lingkungan tempat tinggal murid.

\section{PEMBAHASAN}

Berdasarkan data hasil penelitian di lapangan melalui wawancara tentang pengelolaan sistem pembelajaran dari rumah melalui model dalam jaringan TK Al Muhajirin kota Malang saat pandemi covid-19, dalam hal ini peneliti akan memaparkan hasil di lapangan untuk dikaji melalui teori-teori yang relevan untuk mendeskripsikan dan menganalisis temuan penelitian sebagai berikut:

\section{Pelaksanaan Pembelajaran Dari Rumah TK AI Muhajirin Kota Malang Saat Pandemi Covid 19}

Pembelajaran jarak jauh secara konsepsional merupakan interaksi antara dua pihak, yaitu guru dan peserta didik yang berada dilokasi berbeda. Hal ini bertolak belakang dengan kondisi pembelajaran dengan sistem tatap muka yang menharapkan guru dan murid untuk dapat berada di lokasi dan waktu yang sama. Perbedaan proses pembelajaran tatap muka dan pembelajaran jarak jauh juga terletak pada proses interaksi antara guru dan murid, manajemen, teknologi dan sebagainya (Munir, 2009).

Perencanaan pembelajaran dari rumah di TK Al Muhajirin Kota malang dilakukan dengan beberapa tahapan melakukan proses koordinasi dan pengarahan dari sekolah kepada orangtua tata cara belajar anak pada saat di rumah. Selain itu, guru menyiapkan 
materi berlajar anak dalam bentuk tema-tema pembelajaran dan menyiapkan grup Whatsapp sebagai media pembelajaran dalam Jaringan. Pembelajaran yang dilakukan oleh TK Al Muhajirin Kota Malang ini tidak sama dengan lembaga pendidikan seperti menggunakan Google Classroom, Learning Management System (LMS) atau sebagainya. Sekolah menyesuaikan dengan kondisi peserta dan lingkungan keluarga. Hal ini dilakukan sesuai dengan prinsip pembelajaran jarak jauh, di mana pembelajaran jarak jauh dilaksankan atas dasar kebebasan, kemandirian, keluwesan, terbaru, kesesuaian, pergerakan dan efektivitas. Hal ini dilakukan oleh TK Al Muhajirin Kota Malang dengan tujuan untuk memberikan pembelajaran selama anak di rumah karena wabah Covid-19 dengan suasana belajar peserta didik berbasis lingkungan yang terjangkau dan memudahkan orang tua dalam pendampingan anak selama proses pembelajaran di rumah.

Fleksibilitas dalam perencanaan pembelajaran di TK Al Muhajirin Kota Malang dilakukan dengan upaya untuk membelajarkan siswa sesuai dengan kondisi yang dialami peserta didik selama belajar di rumah. perencanaan pembelajaran guru dapat menentukan, menetapkan, melakukan inovasi pembelajaran untuk memaksimalkan target pengajaran yang diharapkan (Hamzah B. Uno, 2009). Pemnentuan, penetapan dan pengembangan metode pembelajaran yang dilatar belakangi pada keadaan pengajaran yang ada. Aktivitas ini pada dasarnya merupakan inti dari perencanaan pembelajaran. Dalam rancangan pembelajaran yang dilaksanakan oleh TK AI Muhajirin Kota Malang tidak sama cara belajarnya dengan anak pada saat sekolah di dalam kelas dengan tema-tema yang disiapkan oleh guru, tetapi dalam peraktiknya sekolah memberikan arahan kepada para wali murid untuk dapat mengenalkan kepada anak aktifitas yang ada di rumah yang sudah disiapkan oleh sekolah dengan tema belajar dan juga sekolah memberikan kebebasan belajar anak di rumah walaupun tidak berbasis tema. Merancang kegiatan anak dalam belajar menjadi inti dalam capaian untuk mencapai perkembangan anak yang optimal ((Alia \& Irwansyah, 2018); (Amini, 2015);(Martin \& Betrus, 2020); (Pagestu, 2017); (Toki, E. I. \& Pange, 2014))

Prinsip-prinsip pembelajaran jarak jauh, yaitu kemandirian, keluwesan, pergerakan dan efektif (Artyana, 2014). Selain itu, merencanakan pelaksanaan pembelajaran merupakan rancangan bagi guru dalam melaksanakan aktivitas bermain untuk memfasilitasi anak dalam proses pembelajaran. Rencana pelaksanaan pembelajaran dibuat oleh guru sebelum kegiatan pembelajaran dilaksanakan secara daring. Rencana pembelajaran harus berpedoman kepada karakteristik (usia, sosial budaya, dan kebutuhan individual) peserta didik (Wahyuni, Yuliantina, \& Utin Ritayanti, 2018). Seperti halnya pembelajaran dari rumah TK Al Muhajirin Kota Malang guru dalam merencanakan pembelajaran di sesuaikan dengan kebutuhan dan kondisi anak yang berada di Kota Malang khususnya lowokwaru dengan tanpa teknologi yang memadai seperti website, LMS, namun pembelajaran dilaksanakan dengan media Whatsapp.

Lembaga TK muhajirin kota malang dalam perencanaan pembelajaran open and distance learning ini dengan merencanakan suatu pembelajaran yang memudahkan kepada anak didiknya yang rata-rata usia 2-4 tahun dengan tetap mepertimbangkan dan memperhatikan perbedaan karakteristik perkembangan anak, perbedaan latar belakang keluarga, kemampuan memahami, kondisi dalam belajar, serta sarana dan sumber yang tersedia. Sehingga dalam praktinya pembelajaran open and distance learning direncanakan dengan sesuai tema dan juga anak diberikan kebebasan memilih jam belajar bersama orang tua. Perencanaan pembelajaran di TK AI Muhajirin Kota Malang ini dirancang untuk mengajak anak bermain sambil belajar dengan tujuan untuk memberikan samangat tetap belajar walaupun ada di rumah.

Pelaksanaan pembelajaran adalah aktivitas untuk mewujudkan rencana pembelajaran yang sudah direncanakan dari awal agar menjadi teresialisasi dalam rangka mencapai tujuan secara efektif dan efisien (Mulyasa, 2012). Sedangkan pelaksanaan pembelajaran merupakan implementasi dari rencana kegiatan pembelajaran. Sehebat apapun kurikulum yang telah disusun dan dirancang guru, keberhasilannya sangat bergantung pada pelaksanaan dari rancangan tersebut oleh 
guru dikelas, karena guru yang melakukan interaksi dikelas (Rusman, 2011). Tetapi dalam pelaksanaan pembelajaran dari rumah di TK AI Muhajirin, guru sebagai fasilitator orang tua, sedangkan posisi orang tua di rumah pendamping anak belajar di rumah. Guru diharapkan dapat menjalin kerjasama dengan orang tua selama pembelajaran daring, karena pada saat pandemi ini orang tua yang melaksanakan atau mengimplementasikan aktivitas yang disusun oleh guru (Daryanto, 2011). Proses komunikasi adalah hasil (output) dan manfaat (outcome) dari proses kegiatan komunikasi tersebut. Orangtua sebagai pemegang peran utama pada masa lockdown ini untuk menjadi pendamping dan evaluator dalam pelaksanaan pembelajaran dirumah. Selain itu, orang tua sebagai tempat pertama yang memahami perkembangan anak, menjadi pemegang keputusan dalam pelaksanaan pembelajaran dan guru anak selama di rumah. Perkembangan anak dipengaruhi oleh orang tua yang intensitasnya tinggi dalam melakukan interaksi, komunikasi baik secara verbal dan non verbal, dan melakukan pengawasan terhadap kegiatan yang dilaksanakan anak selama proses pembelajaran dan bermain di rumah (Nuraeni, 2016). Melalui proses pelaporan kegiatan anak yang dilaksanalan oleh orang tua kepada pihak sekolah terutama guru kelas untuk menjadikan pedoman bagi guru sebagai bahan evaluasi dalam pelaksanaan pembelajaran.

Dalam pelaksanaan program anak belajar di rumah, Kepala TK Al Muhajirin Kota Malang dan guru kelas selalu mendampingi orang tua melalui media Whatsapp dan guru memberikan kebebasan pada orang tua tentang anak belajar setiap harinya, muai dari belajar membantu orang tua, bermain, ikut melaksanakan ibadah atau membaca doadoa dan surat pendek sebagai aktifitas pembelajaran anak di rumah. Tanpa adanya komunikasi yang baik antara guru sebagai pembimbing atau tutor bagi orang tua dalam melaksanakan pembelajaran jarak jauh ini berjalan dua arah saling aktif, maka pembelajaran daring anak usia dini tidak akan berjalan maksimal (Marsh, 2008). Orang tua mempunyai peran sangat penting ketika anak berada di rumah. Partisipasi orang tua dalam pembelajaran anak selama di rumah sangat penting untuk mengembangkan potensi anak berkembang scara baik mulai dari potensi kognitif, sosial emosional, seni dan keagamaan anak usia dini.

Proses pembelajaran jarak jauh yang dilaksanakan di TK Al Muhajirin Koata Malang memanfaatkan media Whatsapp sebagai sarana pemebelajaran daring atau pembelajaran anak di rumah dengan orang tua sebagai guru selama liburan pandemic Covid-19. Ada beberapa bentuk kegiatan pelaksanaan pembelajaran dari rumah di TK Al Muhajirin Kota Malang sebagai berikut: Pertama, tema dapurku. Kegaitan pembelajaran ini pembelajaran bertujuan mengembangkan motorik kasar dan socialemosional anak, dengan partisipasi anak di dapur saat orang tua memasak anak bias menggerakan anggota badan, tangan, kaki dan semua badan lainnya dengan mengikuti aktifitas ibu selama di dapur dapat membantu mengembangkan motorik kasar anak. Sedangkan social-emosional anak dapat dilihat dari aktifitas anak selama di dapur seperti sikap membantu ibu, atau ibu minta tolong kepada anak hal-hal kecil seperti mengambil piring atau anak diajak mencuci piring. Kegiatan ini dapat mengembangkan sikap social-emosional anak untuk selalu membantu orang lain yang membutuhkan. Kedua, tema anak pintar dan cerdas. Dalam kegiatan ini orang tua secara kontinu mendampingi anak membaca doa-doa dan surat-surat pendek, setiap hari selama anak melakukan aktivitas makan, minum dan ke kamar mandi mandi orang tua selalu mendampingi anak untuk membaca doa. Selain itu menyanyi bersama dan membuat projek untuk menghasilkan sesuatu. Kegiatan ini dilakukan untuk mengembangkan kemampuan kognitif anak dari membaca dan mengingat yang biasa dilakukan di sekolah. Partisipasi orangtua terhadap pendampingan pembelajaran dirumah selama wabah covid-19 ini, sangat menentukan apakah anak akan belajar di rumah bersama orang tua. Dengan demikian partisipasi aktif orang tua berperan penting dalam rangka ikut mengoptimalkan pertumbuhan dan perkembangan anaknya selama belajar di rumah, karena sejatinya pendidikan keluarga adalah pendidikan yang utama (madrasatul ula). Lingkungan keluarga memberikan lingkungan dan sarana belajar yang 
aman, berinteraksi dengan anak secara intelektual dan emosional, memberikan kebebasan anak untuk dapat bereksplorasi mengembangkan potensinya ke arah perkembangan yang lebih baik(Jalal, 2004).

\section{Evaluasi Pembelajaran Dari Rumah TK AI Muhajirin Kota Malang Saat Pandemi Covid 19}

Evaluasi merupakan sebuah proses memahami, memberi arti, memperoleh dan menginformasikan suatu data untuk keperluan pengambil keputusan, dalam hal ini keputusan terhadap apa saja yang sudah dilakukan dalam proses pembelajaran (Sukardi, 2008). Evaluasi pembelajaran dalam jaringan di TK Al Muhajirin Kota Malang dilakukan oleh guru kelas dengan model evaluasi harian dan mingguan. Tujuan evaluasi bagi sekolah yaitu untuk mengetahui perkembangan anak dari kognitif, seni, sosial emosional dan keagamaan dan moral anak selama belajar di rumah bersama orang tua. Konsep Wrigstone bahwa evaluasi pendidikan adalah penaksiran terhadap perkembangan dan pertumbuhan anak ke arah tujuan-tujuan atau nilai-nilai yang telah di tetapkan dalam kurikulum (Purwanto, 2000).

Evaluasi pembelajaran jarak jauh TK Al Muhajirin Kota Malang ini dengan beberapa model evaluasi yang dilakukan oleh guru antara lain: Pertama, evaluasi harian. Guru setiap hari mengevaluasi kegiatan belajar anak yang diunggah oleh wali murid di grup Whatsapp dengan memberikan nilai dengan penyebutan anak pintar, anak cerdas dan anak hebat dan juga tanda jempol di grup Whatsapp. Kedua, dialog. Guru dalam melakukan evaluasi dengan metode percakapan (dialog) langsung dengan anak didik seperti menanyakan kabarnya dan menanyakan aktiftas yang dilakukan di rumah. Ketiga, penugasan dan hasil karya wisata. Kegiatan evaluasi yang dilakukan yaitu dengan memberikan tugas kepada anak untuk menggambar barang mainan, hewan binatang yang dimiliki ana. Evaluasi ini biasanya dalam evaluasi pembelajaran anak dikenal dengan istilah hasil karya. Sedangkan perintah guru kepada anak untuk rajin membantu ibu di rumah dalam rangka evaluasi model penugasan kepada selama proses belajar di rumah. Keempat, interview wali murid. Evaluasi model interview atau wawancara langsung kepada orang tua tentang aktivitas anak selama belajar d rumah dan lebih jauh guru menanyakan langsung kepada wali murid lewat chat pribadi Whatsapp jika selama sehari ada orang tua yang tidak mengunggah kegiatan belajar anaknya di grup Whatsapp wali murid. Evaluasi pembelajaran yang dilakukan oleh guru TK Al Muhajirin ini menjadi acuan guru untuk mengetahui perkembangan potensi yang dimiliki peserta didik selama proses pembelajaran jarak jauh berlangsung.

\section{Kendala Pembelajaran Dari Rumah TK AI Muhajirin Kota Malang Saat Pandemi Covid 19}

Pernyataan para guru tersebut sesuai dengan hasil paparan penelitian sebelumnya bahwa kendala pelaksanaan pembelajaran jarak jauh atau dikenal sebagai darin yang digunakan merupakan kendala pengajaran dalam penggunaan Teknologi Informasi dan Komunikasi atau TIK ((Fauzan \& Pimada, 2018); dan (Asiah, 2016)), kendala pengajaran dalam menyusun perencanaan pembelajaran (Sum \& Taran, 2020), kendala pengajaran berupa minimnya komunikasi (Roach \& Lemasters, 2006), kendala pengajaran berupa kesulitan mengakses selain materi (Winter, Cotton, Gavin, \& Yorke, 2010), kendala pengajaran berupa minimnya kemampuan guru dalam melaksanakan penilaian pembelajaran daring (Sari \& Setiawan, 2020), kendala teknologi yaitu kurangnya tersedianya akses internet dan lemahnya sinyal untuk menjangkau beberapa daerah ((Harjanto \& Sumunar, 2018); dan (Suhartanto, 2010)) dan kumpulan beberapa permaslahan yang berkaitan dengan TIK (Pangondian, Santosa, \& Nugroho, 2019).

Dari analisis pelaksanaan daring di atas dan kurang maksimalnya dalam pelaksanaan di sekolah untuk menunjang kegiatan belajar dari rumah menjelaskan bahwa para guru PAUD masih menemui kendala pelaksanaan pengajaran. Hal ini disebakan guru belum pernah mendapatkan pelatihan terkait pembelajaran daring untuk pembelajaran jarak jauh, minim pengalaman dalam melaksanakan pembelajarn berbasis e-learning untuk mendukung program belajar dari rumah, dan belum 
memperoleh pelatihan secara langsung dalam penerapan pembelajaran daring untuk pembelajaran jarak jauh. Selain itu tidak adanya patokan jelas untuk melaksanakan pembelajaran e-learning untuk mendukung pelaksanaan belajar dari rumah. Kebenyakan guru melaksanakan pembelajaran berbasis daring dengan cara belajar secara mandiri. Serta menyesuaikan kemampuan orangtua walimurid dalam penggunaan media pembelajaran yang dimiliki

Kendala pengajaran dalam penerapan terkait tidak konsistennya guru, menejemen waktu yang minim, dan terdapat materi pelajaran yang tidak dapat dilaksanakan ke dalam pembelajaran daring (Asiah, 2016). Para guru juga dihadapkan permaslahan penerapan TIK dalam pembejaran yaitu masalah ketidakmampuan guru dalam menggunakan perangkat teknologi (Fauzan \& Pimada, 2018). Dikarenakan sebelum adanya pendemik guru mengajar secara klasikal dan menggunakan metode pengajaran tradisional secara tatap muka

Kendala pengajaran mulai terlihat dari ketidakmampuan guru merancang rencana pembelajaran untuk diterapkan di pembelajaran daring, pemilih media yang akan digunakan, pemilih metode, penggunaan alat-alat evaluasi yang akan diterapkan, dan penyelenggaraan pembelajaran dengan interaksi yang maksimal. Terutama untuk menyusun perencanaan pembelajaran yang menarik dan bermaknamasih kesulitan (Sum \& Taran, 2020). Kendala untuk menciptakan suasana pembelajaran berbasis daring yang menyenangkan apabila perencanaan dalam RPP yang dirancang tidak menunjukkan proses pembelajaran yang menarik.

Kendala pengajaran berupa kurangnya interaksi saat pembelajaran dari rumah dan proses pembelajaran ini tidak hanya berlangsung pada jenjang pendidikan di terendah hingga tertinggi di perguruan tinggi. Menurut penelitian pembelajaran berbasis daring di perguruan tinggi juga menemui kendala interasksi berupa miskomunikasi, kurang jelasnya harapan atau tujuan pembelajaran, kurang jelasnya tugas yang diberikan bahkan ada kendala keamanan data (Roach \& Lemasters, 2006). Pelaksanaan daring memiliki sejumlah keunggulan dan kelemahan. Salah satu kelemahan terkait pengajaran yaitu dalam pemilihan materi pembelajaran dan nonpembelajaran. Ketika siswa sedang belajar dengan daring, siswa ada yang mengerjakan tugas yang diberikan oleh guru tapi ada juga yang membuka informasi lain para perangkat pembelajaran yang sedang dibuka (Winter et al., 2010).

Tergolong kendala pengajaran lainnya adalah kemampuan orang tua untuk memanfaatkan perangkat elektronik dan gadget yang dimilikinya untuk memfasilitasi pembelajaran anak di rumah. Hal ini dikarenakan lebih banyak masyarakat yang memanfaatkan smartphone hanya untuk bersosial media. Sementara itu dari lembaga terkait seperti kemendikbud dan Kemenag belum ada pedoman bagi orang tua dalam melaksanakan pembelajaran daring anak selama masa Covid-19 ini. Terdapat pemaparan data terkait Orang tua di berbagai media masa yang mengalami kebingungan selama mendampingii anaknya belajar di rumah.

Jika orang tua murid memiliki perangkat elektronik dan gadget terdapat kendala lain yang dihadapi berupa kepedulian orang tua atau waktu luang untuk mendampingi anak selama proses pembelajaran. Selama pembelajaran daring di rumah perlu adanya keterlibatan orang tua dalam pelaksanaan pembelajaran daring di PAUD mutlak dibutuhkan. Hasil penelitian menjelaskan terdapat beberapa faktor yang memberi dampak atas keterlibatan orang tua di PAUD dalam mengasuh anak diantaranya faktor lingkungan keluarga (Irma, Nisa, \& Sururiyah, 2019). Maka guru perlu tahu lingkungan keluarga dari masing masing siswa dan melibatkan orang tua aktif berpartisipasi untuk mendampingi anak belajar di rumah.

Kendala teknologi seperti yang telah dipaparkan, tidak hanya yang dihadapi para guru dan murid atau orang tua murid antara lain terkait prasarana dan sarana e-learning. Kendala prasarana terkait dengan ketersediaan infrastruktur internet dan jaringan mobile phone. Di Indonesia, layanan internet dapat menyebar keseluruh wilayah dan keterjagkuannyaserta kestabilan jaringan. Juga jika mengakses platform banyak dalam satu kelompok, maka akan menyebabkan overload ((Bao, 2020); (Pramudibyanto, 
Khasanah, \& Widuroyekti, 2020)). Serta permasalahan yang dihadapi dalam pelaksanaan pembelajaran daring ialah belum adanya pedoman yang sesuai saat situasi seperti saat ini, ketersediaan sarana dan prasarana yang belum mencukupi, seperti teknologi dan jaringan internet serta kemampuan sumber daya manusia itu sendiri, salah satunya guru. Sehingga dengan keadaan yang sedang terjadi menuntut tenaga pendidik dan guru untuk lebih adaptif serta inovatif untuk melaksanakan pembelajaran sesuai kondisi lapangan((Ahmed, Shehata, \& Hasanien, 2020); (Arifa, 2020))

Di Indonesia tidak ada penetapan pedoman pelaksanaan pembelajaran daring dari pemerintah dan kurang maksimalnya penggunaan situs e-learning. Sehingga hasil dalam pelaksanaan e-learning tergolong tidak maksimal. Selain itu, faktor utama adalah prasarana dasar yang tidak memadahi terutama terkait ketersediaani internet (Suhartanto, 2010). Penelitian yang lain mengungkap bahwa selain faktor pengajaran, faktor teknologi adalah penentu keberhasilan dalam pelaksanaan daring. Terdapat tiga dimensi sistem yang mencakup beberapa hal yaitu kualitas lembaga dan pelayanan, kualitas informasi dan pembelajaran, dan kualitas sistem dan infrastruktur (Pangondian et al., 2019).

Ketersediaan fasilitas di rumah merupakan salah satu permasalahan yang dihadapi oleh orang tua dalam melaksanakan pendampingi anaknya dalam proses pembelajaran di rumah saat situasi wabah virus corona ini. Hal ini diperkuat dengan pendapat (Wulandari, 2018) menjelaskan bahwa fasilitas itu sangat berpengaruh dalam pendidikan anak yaitu mencapai $82 \%$ sangat baik. Dari hal ini menunjukkan bahwa fasilitas sangat dibutuhkan untuk bisa belajar dengan baik di rumah.

\section{KESIMPULAN}

Berdasarkan paparan data kegiatan penelitian dapat ditarik simpulan bahwa sistem pelaksanaan pembelajaran dari rumah melalui model dalam jaringan atau di sebut belajar dari rumah TK Al Muhajirin Kota Malang saat pandemi covid 19 terdapat beberapa hal yang dibahas diantaranya pelaksanaa, evaluasi dan kendala dalam pelaksanaan pembelajaran dari rumah. Pelaksanaan pembelajaran dari rumah ini perlu adanya kerjasama antara orangtua dan sekolah agar dapat terlaksana dengan maksimal. Dalam proses pembelajaran dari rumah ini pemeran utamanya adalah orangtua. Selain itu perlunya pendampingan secara berkala dalam pelaksanaan pembelajaran dari rumah dengan berkomunikasi secara aktif dengan orangtua. Dalam proses pelaksanaan pembelajaran dari rumah guru dan orangtua dituntut untuk kreatif dan inovatif dalam pembuatan dan pelaksanaan pembelajaran untuk meminimalisir dana dan ketersediaan alat serta bahan yang ada dirumah orangtua. Kegiatan pembelajaran didiesain sefleksibel mungkin agar mudah diterapkan di rumah oleh orangtua. Bentuk kegiatan pembelajaran dirumah berupa projek yang menghasilkan produk agar anak tidak merasa bosan karena dilakukan sembari bermain tapi anak dapat terstimulus secara maksimal. Dalam pelaksanaan pembelajaran dirumah lebih menekankan pada kecakapan hidup anak melalui proses dan pembiasaan.

Untuk pelaksanaan evaluasi sendiri dilakukan secara harian dan mingguan. Penilaian didapat dari hasil kiriman pelaksanaan pembelajaran oleh orangtua. Untuk mendukung data yang diberikan orangtua, guru juga melakukan video call untuk melakukan perbincangan langsung kepada anak agar mengetahui kondisi perkembangan anak. Selain itu, melakukan tanya jawab ke anak, guru juga melakukan tanya jawab keorangtua tentang kendala yang dihadapi selama pelaksanaan pembelajaran dari rumah.

Sedangkan untuk kendala kendala yang dihadapi dikelompokan menjadi dua yaitu pengajaran dan teknologi. Untuk kendala pengajaran hal ini merupakan kondisi baru yang dialami oleh seluruh sekolah dan belum pernah adanya pelatihan dan pendampingan khusus sebelumnya. Sedangkan, untuk kendala teknologi kemampuan menggunakan teknologi rendah, keterbatasan waktu, pememilih media yang kurang tepat untuk pembelajaran dirumah, pemilihan aplikasi, metode pengajaran, proses 
evaluasi yang autentik, dan kurangnya interaksi saat pelaksaan pembelajaran yang disebabkan kendala waktu dan jarak, serta kurangnya perhatian orang tua siswa dalam pendampingi anaknya saat belajar dari rumah; sedangkan untuk kendala teknologi berupa kurangnya prasarana berupa jaringan internet/wifi, lemahnya sinyal mobile phone, belum dimilikinya perangkat elektronik seperti smartphone, terkendalanya untuk kemampuan penggunaan perangkat media elektronik pintar untuk mendukung pelaksanaan e-learning sebagai media pembelajaran jarak jauh

\section{DAFTAR RUJUKAN}

Ahmed, S., Shehata, M. H., \& Hasanien, M. (2020). Emerging Faculty Needs For Enhancing Student Engagement On Virtual Platform. MedEdPublish. Retrieved from https://doi.org/http://doi.org/10.15694/mep.2020.000075.1

Alia, T., \& Irwansyah. (2018). Pendampingan Orang Tua pada Anak Usia Dini dalam Penggunaan Teknologi Digital. A Journal of Language, Literature, Culture and Education, 14(1), 65-78. Retrieved from https://doi.org/10.19166/pji.v14i1.639

Amini, M. (2015). Profil Keterlibatan Orang Tua dalam pendidikan anak usia TK. Jurnal Ilmiah VISI PPTK PAUDNI, 10(1), 9-20. Retrieved from http://journal.unj.ac.id/jurnalfip/index.php/visi/article/view/7/8

Arifa, F. N. (2020). Tantangan pelaksanaan kebijakan belajar dari rumah dalam masa darurat COVID-19. Bidang Kesejahteraan Sosial Kajian Singkat Terhadap Isu Aktual Dan Strategi, $1-7$.

Artyana, E. R. (2014). Tantangan pelaksanaan kebijakan belajar dari rumah dalam masa darurat COVID-19. Bali. Retrieved from http://repository.unikama.ac.id

Asiah, N. (2016). Inovasi Pembelajaran Pendidikan Agama Islam melalui E Learning di SMA Budaya Bandar Lampung. Jurnal MUDARRISUNA: Media Kajian Pendidikan Agama Islam, 6(1), 77-101. Retrieved from http://dx.doi.org/10.22373/jm.v6i1.894.

Bao, W. (2020). COVID-19 and online teaching in higher education: A case study of Peking University. WILEY, (Hum Behav \& Emerg Tech.), 1-3.

Daryanto. (2011). Ilmu komunikasi. Bandung: Sarana Tutorial Nurani Sejahtera.

Fauzan, U., \& Pimada, L. H. (2018). ICT-Based Teaching of English at Madrasah Aliyah in Kalimantan. TARBIYA: Journal of Education in Muslim Society, 5(2), 193-211. Retrieved from https://dx.doi.org/10.15408/tjems.v5i2.10414

Hamzah B. Uno. (2009). Model Pembelajaran Menciptakan Proses Belajar Mengajar yang Kreatif dan Efektif. Jakarta: PT Bumi Aksara.

Harjanto, T., \& Sumunar, D. S. E. W. (2018). Tantangan Dan Peluang Pembelajaran Dalam Jaringan: Studi Kasus Implementas Elok (E-Learning: Open For Knowledge Sharing) Pada Mahasiswa Profesi Ners. Jurnal Keperawatan Respati Yogyakart, 5, 24-28.

Hodgetts, D. J., \& Stolte, O. M. (2012). Case-based research in community and social psychology: Introduction to the special issue. Journal of Community \& Applied Social Psychology, 22, 379-389. Retrieved from https://doi.org/10.1002/casp.2124

Irma, C. N., Nisa, K., \& Sururiyah, S. K. (2019). Keterlibatan Orang Tua dalam Pendidikan Anak Usia Dini di TK Masyithoh 1 Purworejo. Jurnal Obsesi: Jurnal Pendidikan Anak Usia Dini, 3(1), 214-224. Retrieved from https://doi.org/10.31004/obsesi.v3i1.152.

Jalal, F. (2004). Peran Pendidikan Non Formal dalam Pembangunan Manusia Indonesia yang Cerdas dan Bermutu. Universitas Negeri Yogyakarta.

Kronologi dan Urutan Munculnya 6 Orang Positif Virus Corona di Indonesia. (2020). Kompas. Retrieved from https://nasional.kompas.com/read/2020/03/09/05280011/kronologi-danurutan-munculnya-6-orang-positif-virus-corona-di-indonesia

Mahbub, M., Purnamawati, D., Maslamah, Sopakua, S., \& Fauziddin, M. (2020). Educational data mining with clustering technique on the distribution of civil servant teachers in Indonesia. Journal of Advanced Research in Dynamical and Control Systems, 12(6), 2097-2103. Retrieved from https://doi.org/10.5373/JARDCS/V12I6/S20201171

Marsh. (2008). Partisipasi Orangtua dalam Pengambilan Kebijakan Publik Bidang Pendidikan di Kota Surakarta. Universitas Negeri Yogyakarta.

Martin, F., \& Betrus, A. K. (2020). Digital Media for LearningTheories, Processes, and 
Solutions. Switzerland: Springer. Retrieved from https://doi.org/10.1007/978-3-03033120-7

Mulyasa. (2012). Manajemen PAUD. Bandung: PT Remaja Rosdakarya.

Munir. (2009). Pembelajaran Jarak Jauh Berbasis Teknologi Informasi Dan Kominukasi. Bandung: CV. Alfabeta.

Nuraeni, A. (2016). Peran Orang Tua dalam Pengembangan Literasi Dini Anak Kelompok B di Gugus 7 Mangunan Dlingo Bantul. Jurnal Pendidikan Anak Usia Dini, 3, 245-256. Retrieved from http://journal.student.uny.ac.id/ojs/index.php/pgpaud/article/viewFile/1256/1131

Pagestu, R. (2017). Fenomena Gadget Dan Perkembangan Sosial Bagi Anak Usia Dini. Indonesian Journal Of Islamic Early Childhood Education, 2(2)Pagest, 165-173.

Pangondian, R. A., Santosa, P. I., \& Nugroho, E. (2019). Faktor-Faktor Yang Mempengaruhi Kesuksesan Pembelajaran Daring Dalam Revolusi Industri 4.0. In Seminar Nasional Teknologi Komputer \& Sains (SAINTEKS).

Pemerintah Tetapkan Status Wabah Covid-19 Sebagai Bencana Nasional. (2020). Trubus.

Pramudibyanto, H., Khasanah, D. R., \& Widuroyekti, B. (2020). Pendidikan dalam masa pandemik COVID-19. Jurnal Sintesa, 10(1), 41-48.

Purwanto, M. N. (2000). Psikologi Pendidikan. Bandung: Remaja Rosdakarya.

Roach, V., \& Lemasters, L. (2006). Satisfaction with online learning: A comparative descriptive study. Journal of Interactive Online Learning, 5(3), 317-332.

Rusman, dkk. (2011). Pembelajaran Berbasis Teknologi Informasi dan Komunikasi: Mengembangkan Profesionalisme Guru. (PT. Raja Grafindo Persada., Ed.). Jakarta.

Sari, K. M., \& Setiawan, H. (2020). Kompetensi Pedagogik Guru Dalam Melaksanakan Penilaian Pembelajaran Anak Usia Dini. Jurnal Obsesi: Jurnal Pendidikan Anak Usia Dini, 4(2), 900-912. Retrieved from https://doi.org/10.31004/obsesi.v4i2.478

Suhartanto, H. (2010). Survei 2009: Mutu Situs E-Learning Sekolah Indonesia Masih Sangat Minim. Jurnal Sistem Informasi, 6(1), 80-83. Retrieved from https://doi.org/10.21609/jsi.v6i1.280

Sukardi. (2008). Metodologi Penelitian Pendidikan, Kompetensi dan Praktiknya. Jakarta: PT. Bumi Aksara.

Sum, T. A., \& Taran, E. G. M. (2020). Kompetensi Pedagogik Guru Paud Dalam Perencanaan Dan Pelaksanaan Pembelajaran. Jurnal Obsesi: Jurnal Pendidikan Anak Usia Dini, 4(2). https://doi.org/https://doi.org/10.31004/obsesi.v4i2.287

Toki, E. I., \& Pange, J. (2014). Ict Use in Early Childhood Education: Storytelling. Tiltai, 66(1), 183-192. Retrieved from https://doi.org/10.15181/tbb.v66i1.786

Wahyuni, M., Yuliantina, I., \& Utin Ritayanti. (2018). Penyusunan Rencana Pelaksanaan Pembelajaran Pendidikan Anak Usia Dini. Jakarta: Direktorat Pembinaan Pendidikan Anak Usia Dini Direktorat Jenderal Pendidikan Anak Usia Dini dan Pendidikan Masyarakat Kementerian Pendidikan dan Kebudayaan.

Winter, J., Cotton, D., Gavin, J., \& Yorke, J. D. (2010). Effective E-Learning? Multi-Tasking, Distractions And Boundary Management By Graduate Students In An Online Environment. Alt-J, 18(1), 71-83. Retrieved from https://doi.org/10.1080/09687761003657598.

Wulandari, A. (2018). Peran Orang Tua dalam mendampingi Aktivitas Belajar Anak di Rumah pada Lembaga Pos PAUD Beringin Polowijen Kota Malang. Jurnal Ilmu Pendidikan. 